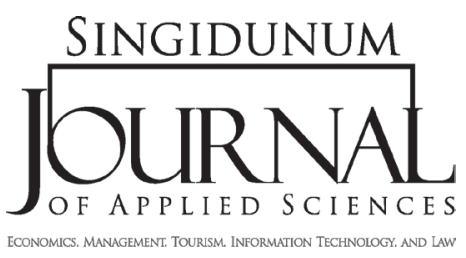

\section{THE LEGAL EFFECTS OF EU DIRECTIVE THROUGH ITS INTERPRETATION}

\author{
Ivan Nikčević, ${ }^{1, *}$, Jovana Parlić2 \\ ${ }^{1}$ Singidunum University, Department of Informatics and Computing \\ 32 Danijelova Street, Belgrade, Serbia \\ ${ }^{2}$ University of Belgrade, Faculty of Law \\ 67 Kralja Aleksandra Boulevard, Belgrade, Serbia
}

SINGIDUNUM JOURNAL 2013, 10 (1): 11-17

ISSN 2217-8090

UDK: 340.132(4-672EU); 341.6(4-672EU)

DOI: $10.5937 /$ sjas $1301011 \mathrm{~N}$

Review paper/Pregledni naučni rad

\begin{abstract}
:
Based on the interpretation of the European Court of Justice regarding the Treaty provisions, the EU Directive creates only a vertical direct effect. However, through judicial interpretation, the Directive achieves diverse and far-reaching effects. Interpretation of national laws by Member State's courts, in accordance with the purpose and wording of the directive, can directly affect private individuals and lead to horizontal direct effect. The European Court of Justice's interpretation of the case based on non- implementation of the directive has created one of the general principles of Community law, in order to mitigate disadvantages and limitations of the doctrine of horizontal direct effect. The interpretation of the directive is gradually expanding the scope of its effects.
\end{abstract}

\section{Key words:}

effects of directives, interpretation, horizontal direct effect.

\section{INTRODUCTION}

The specificity of the European Union that stands out most is the one regarding the judiciary. It had a decisive role in the formation of this political arrangement and it still affects this process. By addressing the ECJ ${ }^{1}$, and through its judgments and rulings, the courts of the Member State undoubtedly had and still have a crucial influence on the construction of a uniform European legal system.

As a form of secondary legislation ${ }^{2}$, Directive requires Member State of European Union to attain a particular goal. They require implementing measures, but at the same time, they do not impose a means for achieving those results. Once directives are adopted, a Member State has a period of time for the implementation. In order to achieve that aim correctly, the state is commonly required to innovate laws. Trough transposition, the state has to bring domestic law in line with the objectives of the directive. When Member State has transposed a directive only in theory and failed to abide by the di- rective in practice, legal action against the state may be initiated in the European Court of Justice. Likewise, the legal action may initiate if the state failed to pass the required national legislation or failed to pass it adequately.

The EC Treaty ${ }^{3}$ does not provide for legislative measures to be directly effective. Following a teleological interpretation, the European Court of Justice created this principle and the criteria ${ }^{4}$ that were more clearly articulated in later cases ${ }^{5}$. In Van Gend and Loos v. Nederlandse ${ }^{6}$, the Court gave a broad and purposive interpretation of the Treaty of Rome $^{7}$, concluding that TEEC ${ }^{8}$ has the features of a constitutional charter of an autonomous community, although concluded between sovereign states by way of international agreement. "The Community constitutes a new legal order of international law for the benefit of which the states have limited their sovereign rights, albeit within limited fields and the subjects of which comprise not only member states but also their nationals. Independently of the legislation of member states, community law... is also 
intended to confer upon them rights... These rights arise not only where they are expressly granted by the treaty, but also by reason of obligations which the treaty imposes in a clearly defined way..." Taking into consideration the wording, purpose and the general spirit of the Treaty, provisions could have a direct effect on individuals, for which benefit they are primarily established.

For the purpose of this paper, direct effect will be considered only in relation to the directive. According to Article 288 TFEU: "A directive shall be binding, as to the result to be achieved, upon each Member State to which it is addressed, but shall leave to the national authorities the choice of form and methods". The European Court of Justice interpreted this article emphasizing the result to be achieved, thus extending the direct effect of directives. The binding effect attributed to directive demands the possibility that the obligation it imposes may be invoked by those concerned. Another reason for direct effect is that the "useful effect" of a directive would be weakened if individuals were prevented from relying on it before their national courts. The effectiveness of EU law is stressed, as such, by the doctrine of direct effect. Likewise, the Member state that failed to adopt the implementing measures required by the directive within the prescribed period may not plead, as against individuals, its own failure to fulfill the obligations that directive entails. The doctrine of direct effect refers to liability of the Member State and emanations of the state for non-implementation of directives by other organs of the State. Regardless of whether the State has introduced national laws to implement provisions, state citizens are able to enforce them by making claims before domestic courts. The three conditions that have to be satisfied in order to make it possible for an individual to rely on direct effect are as follows:

a) the relevant provisions of the directive must be unconditional ${ }^{10}$ and sufficiently clear and precise $^{11}$;

b) the deadline for implementing the Directive must have expired without the directive, or the relevant part of it, having been correctly and completely implemented into the law of the Member State in question;

c) the action must be against the State or an emanation of the State.

However, the European Court of Justice kept limited the impact of directives on vertical direct effect. This effect was hinted in Van Duyn $v$. Home
Office $^{12}$, where the public policy limitations have not prevented the provision of the Directive that provided the freedom of movement to be directly effective. Provision was sufficiently precise and conditional on exercise of independent body discretions which are subject to judicial control.

Preventing enforcement of directives against individuals remains the sole responsibility of the state. Directives are binding exclusively on the Member States to whom they are addressed and require a positive action by the national authorities, not imposing obligations on individuals. In contrast, horizontal direct effect implies that individual may claim its rights deriving from EU law in a dispute against another individual.

\section{THE HORIZONTAL DIRECT EFFECT THROUGH INDIRECT METHODS}

The European Court of Justice has been the main actuator of the European integration process since its establishment. Interpretation rules are not to be found in primary or secondary law. The ECJ $J^{13}$ has exclusive jurisdiction over the interpretation, as a supranational court. Member State court is obliged to guarantee full effectiveness of European law within its jurisdiction. The primacy of an interpretation in accordance with EU law is reflected in obligation of the Member State to interpret law in compatibility with primary law and the conformity with secondary law. More precisely, upon expiry of the deadline for implementation, national court is required to interpret its law in accordance with the directive. Establishing the principle that the courts of the Member States should interpret their national law "in the light of the wording and purpose of the Directive ${ }^{\text {"14 }}$, the European Court of Justice circumvented the limitation of the direct effect. Otherwise excluded, horizontal direct effect may appear through the doctrine of indirect effect. Notwithstanding that in the Von Colson ${ }^{15}$ Case Directive did not meet the requiremets for direct effect, set in Van Gend and Loos, the ECJ held that there was a duty of achieving the result prescribed by the Directive and the duty of ensuring the compliance with this obligation by all concerned authorities, including the courts. This way of interpretation can directly affect and, therefore, disadvantage individuals. When the party against whom the directive is sought to be enforced is a private individual, and therefore direct effect is not applicable, national courts are obliged to construe provisions to comply with directives, 
and thus indirectly apply provisions to individual. The European Court of Justice acknowledged such duty by formulation: "[T]he Member States' obligation arising from a Directive to achieve the result envisaged by the Directive and their duty under Article [4(3) TEU] to take all appropriate measures, whether general or particular, to ensure the fulfillment of that obligation, is binding on all the authorities of Member States including, for matters within their jurisdiction, the courts. It follows that, in applying the national law and in particular the provisions of a national law specifically introduced in order to implement [a Directive], national courts are required to interpret their national law in the light of the wording and the purpose of the directive in order to achieve the result referred to in the third paragraph of Article [288]. ${ }^{16}$ In Marleasing ${ }^{17}$ case, that was litigated among private individuals, the Court held that national courts should decide in a way as to give effect to its obligations under the Community law, so that the question in a dispute is viewed through EU law. This duty is limited by separation of powers by judiciary and legislature, and the consistent interpretation must not lead to the interpretation contrary to the national norm. However, if the national courts cannot interpret provisions in conformity with directives, then the state faces the possibility of compensation by the principle of State Liability.

\section{THE PRINCIPLE OF STATE LIABILITY AS A WAY TO CIRCUMVENT THE LACK OF HORIZONTAL DIRECT EFFECT}

The Member State authorities are primarily responsible for the creation and above all, for the implementation and enforcement of EU law. They are obliged to take all measures necessary to ensure the implementation and adjustment. Article 4(3) of the Treaty contains a legal principle under which national courts are obliged to protect the individual rights conferred by Community law. According to Article 5 of the Treaty, the state is required to take all appropriate, whether general or particular measures, to ensure the implementation of Community law and to nullify the unlawful consequences of its breach. As a result of the failure to enforce EU law, an individual can suffer damage. A general principle of State responsibility, for non-compliance with EU law, was developed by European Court of Justice in order to mitigate disadvantages and limitations of the doctrine of horizontal direct effect. The Eu- ropean Court of Justice created a doctrine of state responsibility for the individual's loss caused by non implementation of the directive. The full effectiveness of EU law would be weakened if individuals were unable to obtain reparation when the rights granted to them are infringed by a breach of EU law for which the State can be held responsible. Before the national courts, an individual may invoke the obligation of the state to compensate for damages caused by its failure to implement a directive.

The principle of State Liability and its elements were created by a case in the field of employment rights, due to the fact that directives provide most of the employment and industrial relations law. In Andrea Francovich and Others $v$. Italian Republic ${ }^{18}$, $\mathrm{ECJ}^{19}$ based its decision primarily on the effective judicial protection and the effect utile doctrines, as a consequence of elementary values underlying the EU legal order. In this sense, the obligation of restitution of damage by Member State is inherent in the system of the Treaty. "The full effectiveness of Community law would be impaired and the protection of the rights that they grant would be weakened...", and the more so as „such a possibility of reparation by the Member State is particularly indispensable where the full effectiveness of Community rules is subject to prior action on the part of the State and where, consequently, in the absence of such action, individuals cannot enforce before the national courts the rights conferred upon them by Community law." 20

Non-compliance with directive may result from partial, incorrect or inadequate implementation, as well as from failure to implement the directive as was the case in Francovich and Bonifaci $v$. Italy. Italian Republic's failure to implement the directive $80 / 987 /$ EEC on the protection of employees in the event of their employers' insolvency had previously been recorded by the European Court of Justice in enforcement proceedings brought by the Commission against the Italy. In Francovich case, a group of employees- Mr. Francovich, Mrs. Bonifaci and 33 more applicants, in the main proceedings were owed wages by their employers, who had become insolvent. Forasmuch as Italy failed to implement the directive 80/987/EEC that aimed to create a mechanism that would guarantee the payment of the wages owed to them, the applicants brought proceedings against the Italian Republic and argued that the Italian state should compensate them their arrears of wages. The European Court of Justice decided that the $80 / 987 /$ EEC Directive's provisions 
are not fully unconditional, clear and sufficiently precise to create a direct effect. Thus, the $\mathrm{EC}{ }^{21}$ considered the question of State Liability without being brought into direct link with the doctrine of direct effect.

Moreover, the Court ${ }^{22}$ introduced the principle indicating that the conditions of the principle depend on the nature of the breach of EU law, giving rise to loss and damage. Three substantive conditions are required:

a) the result prescribed by the directive should entail the grant of rights to individuals.

b) The content of those rights must be capable of being identified on the basis of the provisions of the directive.

c) There must be a causal link between Member State's breach of the obligation and the loss and damage suffered by individuals.

As to the procedural requirements, the European Court of Justice noted that in the absence of EU legislation on this matter, it is on the national law to determine the competent courts and lay down the procedural rules that will provide complete protection of the rights that individuals derive from EU law, in accordance with the principles of equivalence and effectiveness. Therefore, national courts should ensure suitability of domestic tort remedies in such cases, so that they are not less favorable than those governing similar domestic actions. Likewise, national procedural rules shall not render virtually impossible or excessively difficult the exercise of individual's rights in damages.

In the cases that followed the case of Francovich, such as Brasserie ${ }^{23}$, British Telecommunications ${ }^{24}$ and Dillenkofer ${ }^{25}$, the European Court of Justice repeated its recognition of principle, recalling that is on Member State courts to assess the amount of damage, thus ensuring that national law makes possible for individuals to obtain reparation. In Brasserie du Pêcheur and Factortame, clearer conditions were set out:

a) rule of law infringed must be intended to confer rights on individuals,

b) the breach is sufficiently serious and the question is whether the Member State has manifestly and gravely disregarded the limits on its discretion,

c) there is a causal link between breach and damage.

The Court held that the principle of State Liability was not confined to a failure to implement a
Directive but to all acts and omissions (legislative, executive and judicial) infringing Community law, which means breaching all EU laws, irrespective of direct effect.

In British Telecommunications, a requirement that the breach must be sufficiently serious had a decisive influence. To ascertain that this condition is present, clarity and precision of the infringed provision has a decisive role. This condition, as the Court held in Dillenkofer, is applied regardless of the degree of discretion enjoyed by Member States. In later cases ${ }^{26}$ the ECJ elaborated the principle more fully, and eventually spread its implementation.

\section{CONCLUSION}

According to Article 288 TFEU, directives are binding only on the Member States to whom they are addressed and merely with regard to the result to be achieved, leaving the choice of form and method to state authorities. This would mean that the effects of the directive can affect individuals only due to the implementation. The above-mentioned article also emphasizes the difference between directives and regulations, through the wording that only the latter have direct applicability, both vertically and horizontally. However, the European Court of Justice circumvented its own prohibition of horizontal direct effect of directives or at least reduced its significance. Gradually and by the back stairs, the scope of the directive (effect) is expanding. Upon expiry of the deadline for implementation, national court is required to interpret its law in conformity with the directive. The Member State's duty of consistent interpretation can directly affect individuals, and thus lead to horizontal direct effect. Through the case law, the European Court of Justice gave effect to directives in various ways. When considering the issue of state responsibility in Francovich case, the European Court of Justice has not brought it into direct link with the doctrine of direct effect. However, the principle of State Liability was developed in order to mitigate disadvantages and limitations of the doctrine of horizontal direct effect. This case established substantive and procedural conditions of the principle, thus ensuring suitability of domestic tort remedies for its enforcement in such cases. A number of subsequent, post-Francovich cases $^{27}$, were followed by finer and further development of the principle. It is the interpretation of EU law institutes, in case of their violation, that gives them the fuller meaning and contributes to their development. 


\section{REFERENCES}

Albors-Llorens, A. (2010) Keeping up appearances: the Court of Justice and the effects of EU directives. The Cambridge Law Journal. 69 (3), 455-458.

Evangelos, N. (2005) From Francovich to Köbler and beyond: The evolution of a State liability regime for the European Community. Thesis, (LL.M.). University of Helsinki.

Kaeding, M. (2007) Active transposition of EU law legislation. EIPAScope [online]. Available from: http://www. eipa.eu/files/repository/eipascope/20080313162050_ MKA_SCOPE2007-3_Internet-4.pdf [accessed 6 July 2012].

Klamert, M. (2006) Judicial implementation of directives and anticipatory indirect effect: connecting the dots. Common Market Law Rewiev. 43 (5), 1251-1275.

Post-Francovich judgement by the ECJ [online]. Avaliable from: http://www.asser.nl/upload/eel-webroot/www/ documents/cms_eel_id178_1_Post.pdf [accessed 6 July 2012].

Rösler, H. (2007) Interpretation of EU law [online]. Avaliable from: http://fds.oup.com/pdf/13/9780199578955. pdf [accessed 9 July 2012].

\section{Relevant case law:}

Case 26/62, NV Algemene Transporten Expeditie Ondememing van Gend and Loos v. Nederlandse Administratis der Belastingen (1963) ECR 1

Case C 2/74, Jean Rayners v. Belgian State (1974) ECR 631

Case 41/74 Yvonne van Duyn Home Office (1974) ECR 1337

Case 14/83, Von Colson and Elisabeth Kamann $v$. Land Nordrhein-Westfalen (1984) ECR 1891

Case C 106/89, Marleasing SA v. Comercial International de Alimentacion SA (1989) ECR I-4135

Joined cases C-6/90 and C-9/90, Andrea Francovich and Danila Bonifaci and others $v$. Italian Republic (1991) ECR I-05357

Case C 334/92, Wagner Miret $v$. Fondo de Garantia Salarial (1993) ECR I-6911

Case C 91/92 Faccini Dori $v$. Recreb (1994) ECR I-3325 (1995) 1 C.M.L.R. 665

Joined Cases C-46/93 and C-48/93 Brasserie du Pêcheur and Factortame III (1996) ECR I1029

Case C 392/93 R v. HM Treasury, ex parte British Telecommunications (1996) ECR I-1631

Joined Cases C-178, 179 and 188-190/94 Dillenkofer and Others $v$. Germany (1996) ECR I-4845

Joined cases C-397/ 01 to C-403/01, Berhard Pfeiffer and Others $v$. Deutches Rotes Kreuz, Kreisverband Waldshut ev. (2004) ECR I-8835

\section{ENDNOTES}

1 The European Court of Justice

2 Article 288 TFEU (Treaty on the Functioning of the European Union) defines a types of legal acts (Regulations, Directives, Decisions, Recommendations and Opinions) European Community institutions can adopt and explains their nature.

3 Treaty establishing the European Economic Community, EEC Treaty, signed in Rome in 1957, came into force in 1958. The Treaty was replaced by the Treaty of the functioning of the European Union, TFEU, on the entry into force of the Treaty of Lisbon in 2009, which establish the constitutional basis of EU.

4 The European Court of Justice opinion in Case 26/62, NV Algemene Transporten Expeditie Ondermeming van Gend and Loos $v$. Nederlandse Administratis der Belastingen, (1963) ECR 1, is considered to be one of the most important decision which has resulted the development of Community law. A private firm for transportation, named Van Gend and Loos, had imported chemical (urea-formaldehyde) from Germany to Netherlands for which they were billed tariffs on import, higher by $5 \%$, by the Dutch customs authorities. Complaint that the company sent was based on the fact that such a measure of the customs authorities was not in accordance with Article 12 of the Treaty of Rome, TEEC, (current Article 30 TFEU) which stated that: "Member States shall refrain from introducing between themselves any new customs duties on imports and exports or any charges having equivalent effect, and from increasing those which they already apply in their trade with each other." Customs have increased by 5\%, by Dutch custom tariff which came into force in 1960. year, compared with the year 1958. when the Treaty of Rome previously came into force. European Court of Justice preliminary ruling under Article 177 TEEC (current Article 267 TFEU), was about the question of whether"... nationals of a Member State can, on the basis of the Article in question (Art.12 EEC), lay claim to individual rights which the courts must protect." Advocate General's opinion, different from the judgment of the ECJ, was that some Treaty provisions could have "direct effect" but that Article 12 was not one of them. On contrary, ECJ adhered that abovementioned article could create a personal rights for Van Gend en Loos and so, that private individuals could rely on it. The ECJ decided that Dutch authorities could not impose a higher tariff that the one that was in force the time TEEC came into force so that Van Gend and Loos did not have to pay higher tariffs and this right could be enforced before the domestic courts. Treaty provision would be directly effective if, among other, it were unconditional and did not leave any further implementation to the member states.

5 In Case C 2/74, Jean Rayners $v$. Belgian State (1974) ECR 631, European Court of Justice established more precise criteria for vertical dirrect effect. On the grounds that he did not have Belgian nationality M. Reyners, a Dutch national, was prohibited his law practice. Such discrimina- 
tion on the grounds of nationality was forbbiden by the Treaty Article 43. The ECJ opinion was that the princile under this article was clear despite the lack of spesific directives. For a TEEC provision to have a direct effect it is necessary that the three conditions are fulfilled cumulatively: a) the provision must be sufficiently clear and precise b) unconditional c) independent of further action by the national authorities.

6 Op.cit., The European Court of Justice judgement of 5. February 1963.

7 Treaty establishing the European Economic Community, EEC Treaty, signed in Rome in 1957, came into force in 1958. The Treaty was replaced by the Treaty of the functioning of the European Union, TFEU, on the entry into force of the Treaty of Lisbon in 2009, which establish the constitutional basis of EU.

8 Ibid.

9 The European Court of Justice judgement of 5. February 1963.

10 The relevant provision is not a subject of any measure, either by the institutions of the European Community or by the Member States, in its implementation or its effects.

11 The relevant provision has an unambiguous meaning and provides feasible indications to the national court.

12 Case 41/74 Yvonne van Duyn $v$. Home Office (1974), ECR 1337, Ministry of Internal Affairs of the United Kingdom has barred access to the country to Ms. Van Duyn, a Dutch citizen, intended to be employed in the Scientology church. United Kingdom discouraged the Scientology Chirch for the reason of the public intrest. The EC Treaties guaranted the feedom of movement for workes but at the same time allowed restriction of this freedom in the public interest. The conditions under which the State may invoke the public intrest to limit the freedom of movement were prescribed in the relevant Directive. Issue that has raised in this case was whether an individual coluld invoke the Directive before a national court in case against the State. The ECJ held that the limitations of this freedom themselves do not prevent conferning rights on individuals, contained in Article 39(48)(para. 1 and 2.), which are envorceable by them and which the national corts must protect.

13 The European Court of Justice.

14 Joined cases C-397/ 01 to C-403/01, Berhard Pfeiffer and Others $v$. Deutches Rotes Kreuz, Kreisverband Waldshut ev., (2004) ECR I-8835

15 Case 14/83, Von Colson and Elisabeth Kamann v. Land Nordrhein-Westfalen, (1984) ECR 1891. Two female social workers applied for a job in German prison. Both of them were denied although they were placed at the top of the list of applicants. The main reason was that it was considered to be incovinient that women do with mail inmates. They were dicriminated against by the apointment of less well qualified males. Article 6 of the 76/207 Directive on the equal treatment of men and women as regards access to employment, vocational training, promotion and working conditions was infringed, as they claimed. The compensation that could be awarded to them was in- significant. The ECJ held that the failure of German law to provide appropriate compensation was the result of incomplete implementation of the 76/207 Directive. Although this Directive did not meet the requiremets for dirrect effect, the duty of achieving the result prescribed by Directive and the duty of enshuring compliance with this obligation by all concerned authorities, including the Member State courts, was present.

16 Ibid.

17 Case C-106/89, Marleasing SA v. Comercial International de Alimentacion SA (1989), ECR I-4135, The company that has been in the role of claimant sought removal from the register of companies under Spanish law. They claimed that the sole purpose of those companies was about fraud. The deffendant invoked the Directive 68/151, which established the grounds under which a company could be annulled. The European Court of Justice held that defendant could rely on abovementioned Directive for the reason it creates an obligation of implementation.

18 Joined cases C-6/90 and C-9/90, Andrea Francovich and Danila Bonifaci and others $v$. Italian Republic, (1991) ECR I-05357

19 The European Court of Justice.

20 Op.cit., third paragraph.

21 Op.cit.

22 Ibid.

23 Joined Cases C-46/93 and C-48/93 Brasserie du Pêcheur and Factortame III (1996) ECR I1029, The ECJ stressed that in a case the breach of Community law can be attributed to a Member State legislature, in the field in which it has a wide discretion, individuals suffering loss or damage are entitled to reparation when the rule that had been violated for the had purpose of ensuring their rights, the breach is sufficiently serious and there is a direct causal link.

24 Case C-392/93 R v. HM Treasury, ex parte British Telecommunications (1996) ECR I-1631, The Court decided the interpretation of Directive was given by United Kingdom in good faith, and this is way it is not considered to be contrary to the wording of the Directive or to the objective pursued by it. Imprecisely wording by the national courts was not considered as sufficiently serious, add-in the fact no guidance was available to the Member State from case-law of the ECJ as to the interpretation of the provision at issue.

25 Joined Cases C-178, 179 and 188-190/94 Dillenkofer and Others v. Germany (1996) ECR I-4845, The European Court of Justice held that failure to take any measure to transpose a directive within the prescribed period constitutes itself a serious breach and allows a right for reparation for individuals suffering injury, in case the goal of directive entails the right for individuals whose content is identifiable and there is a causal link. The requirement of sufficiently serious breach was evident from its facts, although it was not expressly mentioned in Francovich.

26 With the omission of previously mentioned cases such as Brasserie du Pêcheur and Factortame, British Telecommunications, Dillenkofer and Others, the rest cases which develop further the principle of State Liability include: 
Case C-334/92, Wagner Miret $v$. Fondo de Garantia Salarial, (1993) ECR I-6911, The European Court of Justice confirms the principles established in Francovich in an obiter dictum; Case C-91/92 Faccini Dori $v$. Recreb (1994) ECR I-3325, (1995) 1 C.M.L.R. 665, Member State courts are reminded on duty to interpret national law in conformity with EU law. The ECJ reformulated a requirement for rights in restrictive way, from "the result prescribed by the directive should entail the grant of rights to individuals" into: "the purpose of the directive must be to grant rights to individuals"; The Queen $v$. Secretary of State for Social Security, ex parte Eunice Sutton (1997) ECR I-2163; Joined Cases C-94/95 and 95/95, Danila Bonifaci and others v. INPS (1997) ECR I-3969; Joined Cases C-192-218/95, Comateb and Others $v$. Directeur Général des Douanes et Droits Indirects (1997) ECR I-165; Case C-261/95, Rosalba PalmisaniINPS (1997) ECR I-4025; Case C-373/95, Federica Maso and others INPS and the Italian Republic (1997) ECR I-4051; Case C-127/95, Norbrook Laboratories Ltd v. Ministry of Agriculture, Fisheries and Food (1998) ECR I-1531; Case C-319/96, Brinkman Tabakfabriken GmbH v. Skatteministeriet (1998) ECR I-5255; Case C-131/97, Annalisa Carbonari and others $v$. Universita degli studi di Bologna, Ministero della Sanita, Ministero dell'Universita e della Ricerca Scientifica and Ministero del Tesoro (1999) ECR I-1103; Case C-140/97, Rechberger and Greindl v. Austria (1999) ECR I-3499; C-302/97, Konle v. Austria (1999)ECR I-3099; Case C-321/97, Ulla-Brith Andersson and Susanne Wakeras-Andersson v. Swedish State (1999) ECR I-3551;
Case C-424/97, Salomone Haim v. Kassenzahnartztliche Vereinigung Nordrheim (2000) ECR I-5123; Joined Cases C-387/98 and C-410/98, Metallgesellschaft Ltd and Others, HoechstAG and Hoechst (UK) Ltd $v$. Commissioners of Inland Revenue and HM Attorney General (2001) ECRI-1727; Case C-150/99, Stockholm Lindöpark Aktiebolag $v$. Sweden (2001) ECR I-493; Case C-118/00, LarsyINASTI (2001) ECR I-5063; C-63/01, Samuel Sidney Evans $v$. Secretary of State for Environment, Transport and the Regions and the Motor Insurer's Bureau (2003) ECR I-4447; Case C-224/01,, Gerhard Köbler v. Austria (2003) ECR I-10239; Case C-129/00 Commission $v$. Italy (2003) ECR 14637; Case C-63/01,, Evans $v$. Secretary of State for the Environment, Transport and Regions, Motor Insurers Bureau(2003) ECR I-4447; Case C-201/02, Wells (2004) ECR I-723; Case C 222/02 Paul and Others Case C-470/04, N v. Inspecteur van de Belastingdienst Oost/kantoor Almelo(2006) Germany (2004) ECR I-9425; Case C-173/03, Traghetti del Mediterraneo SpA $v$. Republica Italiana (2006) ECR I-5177; Case C 470/04, N v. Inspecteur van de Belastingdienst Oost/kantoor Almelo (2006) ECR I-7409; Case C-300/04 Eman and Sevinger (2006) ECR I-8055; Case C-446/04, Test Claimants in the Fill Group Littigation (2006) ECR nyr; Case C 278/05 Carol Marilyn Robins and Others $v$. Secretary of State for Work and Pensions (2007) ECR nyr; Case C-524/04 Test Claimants in the Thin Cap Group Litigation (2007), ECR nyr; Case C-555/ 07 Seda Kücükdeveci v. Swedex GmbH and Co. KG, judgment from the 19th January 2010.

27 Ibid.

\section{PRAVNO DEJSTVO DIREKTIVE EVROPSKE UNIJE KROZ NJENO TUMAČENJE}

\section{Rezime:}

$\mathrm{Na}$ osnovu tumačenja Evropskog suda pravde u vezi sa odredbama sporazuma, direktiva Evropske Unije ima samo vertikalno direktno dejstvo. Međutim, kroz tumačenje suda, Direktiva dostiže različita i dalekosežna dejstva. Tumačenje državnih zakona od strane sudova zemlje članice, a koji su u skladu sa svrhom i formulacijom direktive, može direktno da utiče na pojedince i dovede do horizontalnog direktnog dejstva. Tumačenje slučaja od strane Evropskog suda pravde, a koji se zasniva na neprimenjivanju direktive, stvorilo je jedno od opštih principa Komunitarnog prava kako bi se ublažili nedostaci i ograničenja doktrine horizontalnog direktnog dejstva. Tumačenje direktive postepeno utiče na širenje obima njenog dejstva.

\section{Ključne reči:}

dejstva direktiva, tumačenje, horizontalno direktno dejstvo.

Received: July 20th, 2012

Correction: September 27th, 2012 Accepted: November 5th, 2012 